\title{
STATUS OF THE TAXPAYER IN A TAX LEGAL MECHANISM
}

\author{
Volodymyr Uvarov', Dmytro Mirkovets², Viktoriia Zarubei ${ }^{3}$
}

\begin{abstract}
The aim of the article. The theoretical and legal bases of a taxpayer in the tax legal mechanism are considered. A comparative legal study of legal regulations that determine the place of the taxpayer in the tax legal mechanism is conducted, and on this basis, ways to improve domestic legislation in this sphere are determined. The subject of the study is the status of the taxpayer in the tax legal mechanism. Methodology. The research is based on the analysis of legal regulatory acts concerning the tax legal regulation in Ukraine. Based on the comparative legal method of research of certain provisions of Ukrainian legislation, the place of a taxpayer in the tax legal mechanism, as well as the application of positive foreign experience in this field, are determined. The results of the study revealed the need for a detailed study of defining taxpayers, taxable persons. Practical implications. The taxpayer is considered as the most significant element for the existence and development of tax relations. Moreover, the formation and development of compulsory tax payments, the integration of such payments into the tax systems of countries are analysed, which indicates the paramount importance of the taxpayer among any other elements of the tax legal mechanism. Relevance/originality. A comparative analysis of the taxpayer in the tax legal mechanism in foreign countries is the foundation for the improvement of most promising ways for the development of domestic legislation in this sphere.
\end{abstract}

Key words: tax legal mechanism, tax legal relations, subject of tax legal relations, taxpayer.

JEL Classification: $\mathrm{H} 21, \mathrm{H} 26$

\section{The relevance of the topic}

In the legal mechanism of any tax, both among its main and additional elements, the subject or the taxpayer is the most crucial element for the existence and development of tax legal relations. Being an obliged subject of the tax legal relationship, the taxpayer is the only participant in tax and legal relations, which is fixed in the legal mechanism for compulsory tax payments. In addition, the taxpayer actually transfers aspects of will expression, consciousness, and activity (qualities that he/she receives as a subject of tax legal relations) to the legal mechanism. The conscious will, active performance of the taxpayer, his/her lawful behaviour, aimed at creating the relevant juridical facts, will further determine the implementation of other elements of the tax legal mechanism or fees in specific tax legal relations. This specificity and influence on other elements of the tax legal mechanism must be considered by the legislator in the legislative establishment of any taxes and fees. Therefore, an important role of the taxpayer in securing the legal mechanism of one or another compulsory tax payment becomes evident.

\section{Literature review}

A significant contribution to the study of the taxpayer in the tax legal mechanism was made by foreign and domesticscientists, suchasL.V.Avramenko,S.I.Ilovaiskyi, A. A. Isaiev, I. I. Kucherov, N. P. Kucheriavenko, I. Kh. Ozerov, O. V. Petrishin, N. Yu. Pryshva, K. D.-G. Rau, I. T. Tarasov, N. V. Tsvik. The aim of the article is to consider the theoretical and legal bases of the taxpayer in the tax legal mechanism. A comparative legal study of legal regulations that determine the place of a taxpayer in the tax legal mechanism is conducted, and on this basis, ways to improve domestic legislation in this sphere are determined.

\section{The main material}

The historical aspect of the introduction of compulsory tax payments, their integration in the taxation systems of countries demonstrate the paramount importance of the taxpayer among any other elements of the tax legal mechanism. Therefore, the specific nature of the relationship between the state and potential taxpayers becomes the foundation and supporting structure for

\footnotetext{
Corresponding author:

${ }^{1}$ Dnipropetrovsk State University of Internal Affairs, Ukraine.

${ }^{2}$ University of Modern Knowledge, Ukraine.

${ }^{3}$ National Academy of Internal Affairs, Ukraine.

E-mail: zarybey@bigmir.net
} 
the introduction and development of taxation, the legal justification of its grounds, and therefore, the possibility and admissibility of establishing compulsory tax payments. N. Prishva argues (Pryshva, 2004) that the admissibility of introducing taxes, recognizing the state's tax sovereignty is associated with a special qualitative order of the state power that should not only be legitimate but also strong to ensure payment of taxes as free payments.

At the same time, potential taxpayers should be aware of the need to establish their tax duty for the common good and possibility of realizing and protecting their own interests in the territory covered by the tax sovereignty of the state or other territorial formation. It is known (Pryshva, 2004), for example, that in Ancient Greece and Ancient Rome, free population of these countries did not presume the possibility of recognizing themselves as taxpayers, except for special and extraordinary circumstances, which could be martial law and the need to protect the integrity of the state territory; but usually the tax and tax duty were supposed as the state's burden on the subdue and other citizens not possessing full rights. Only with the advent of the Enlightenment, the beginning of a broad social life under the formula "if you possess property, you should allocate its part in favour of the state and under the protection of the latter easy use the rest of the property," the final understanding of the acceptability of tax establishment came. Therefore, not only the possibility of introducing taxes and fees but also the modern role of compulsory tax payments in general as one of the main public legal sources of state revenues directly depended on the realization that all persons who in one way or another take part in public life and take advantage of it should be recognized as potential taxpayers.

The generally recognized classics of financial and legal science assume the primary place and importance of taxpayers for establishing mandatory tax payments. For example, a well-known German specialist in the middle of the XXI century Professor K. D-G. Rau wrote that in order to require tax, first, it is necessary to determine those numerical data, according to which it is easy to evaluate the tax duty of each person. This includes: a) definition of the subject, which should be the measure of tax duty, for example, a certain part of the property, income, expenses, etc.; b) establishment of a tax rate, that is, the rate at which a known amount of tax is determined from a known item; c) determination of the number of items to be taxed that each person is obliged to pay (Rau, 1867). Pre-revolutionary Russian jurist I. T. Tarasov pointed out that by establishing the tax, the law must define with precision the payer, the object, that is, the taxable object, the taxable action, upon which the tax is to be paid, the forms of calculation, orders and receipts, tax control, repayment, penalty, exclusion and management (Tarasov, 2004). Therefore, in all these cases, in establishing mandatory tax payments, scientists emphasized the taxpayer and then around this category they completed the tax legal mechanism or other payment of a tax nature.

The issue of assigning tax duties to certain persons, the definition of taxpayers has maintained its relevance over time and confirmed its significance. I. I. Kucherov argues that the question of taxable persons is one of the main in the theory of taxes and fees. In modern life, the need for everyone to participate in the formation of public finance is no longer questioned; the principle of universal taxation is firmly established in the minds of people acquiring legal significance and legislative consolidation (Kucherov, 2009). Generally, under present conditions, any physical individual or legal entity should take part in the formation of public revenues of state and local budgets, at the expense of his/her property, be involved in financing public expenditures.

Therefore, the most common definitions of the payer (subject) of the tax are based on this. For example, representatives of Russian pre-revolutionary financial thought I. Kh. Ozerov and A. O. Isaev defined the taxpayer as any person, who is legally charged (Ozerov, 1908), concretizing, however, that taxable persons can be both physical individuals and legal entities, corporations, societies, unions, both nationals and foreigners (Isaev, 1887).

However, in this definition, neither formal nor substantive aspects of taxpaying are disclosed in detail. Therefore, in an attempt to explain the formal aspect of bearing the tax by the person, I. I. Kucherov interpreted the taxpayer as an eligible person, who in accordance with the legislation is charged with the duty to pay tax independently and at the expense of own funds (Kucherov, 2009). However, in our opinion, several remarks need to be made to this definition.

First, it is hardly worthwhile to focus separately on the issue of taxpayer legal capacity. Each individual possesses legal capacity (has an abstract ability as a subject of law to acquire subjective legal rights and bear subjective legal obligations) from birth to death. The legal capacity of a legal entity arises from the moment of its state registration, in some cases, the receipt of a license for specially defined activities and terminates with the liquidation of a legal entity. Legal capacity is inherent in all participants of legal relations (Tsvik, Petryshyn, Avramenko et al., 2011). Therefore, the legal personality of the taxpayer would be more appropriate.

Secondly, it should be emphasized that legislation is referred to in a broad sense, that is, not only the actual system of existing laws but also other legal regulations. For example, decisions of local representative bodies on the introduction of local taxes and fees can provide for the tax obligations of the person. For example, in 1992-1993, the powers of the parliament were delegated to the government and the decrees of the Cabinet of Ministers of Ukraine were given the force of law. Finally, international treaties can also be a source of tax laws that affect the content of tax liability in the case of elimination of double taxation. 
Thirdly, the independence of the payer's duty to pay taxes should not be absolutized necessarily. Moreover, under the appropriate instruction or by virtue of law, both the representative of the taxpayer and his/her tax agent can pay money into budget accounts. In addition, in cases of consolidation of the tax obligation, the transfer of the payer's money to the budget is physically performed by another payer of the tax. After all, the tax can be paid from borrowed not only from own funds.

While defining the taxpayer, a combination of the formal and substantial side of the mechanism for a tax duty seems to be more correct. From this perspective, M. P. Kucheriavenko argues that taxpayers are persons who have, receive (transfer) objects of taxation or carry out activities subject to taxation and are entrusted with a tax obligation in accordance with the current tax legislation (Kucheriavenko, 2005). Moreover, the person's possession or entry into the object of taxation or the performance of taxable activities are expressed through a cross-cutting legal category of a juridical fact, therefore, the definition of a taxpayer can be reduced to the formula "a taxpayer is a person with the tax duty imposed by tax laws on juridical facts indicating his/her possession of taxable object".

Therefore, the abovementioned achievements of the legal science determine the definition of a legal taxpayer in the domestic legislation. According to the provision of clause 15.1 of Article 15 of the Tax Code of Ukraine, taxpayers are individuals (residents and non-residents of Ukraine), legal entities (residents and non-residents of Ukraine), and their separate subdivisions that have, receive (transfer) tax objects or carry out activities (operations) that are subject to taxation under this Code or tax laws, and that are charged for paying taxes and fees under this Code (Podatkovyi kodeks Ukrainy, item 15.1, Art. 15). This taxpayer definition is generic. It provides for the general understanding of the taxpayer, which would be suitable for application in any abstractly conceivable tax legal relations.

Moreover, as a phenomenon of legal and social reality, taxation relations consist of the establishment and collection of specific, not imaginary, mandatory tax payments. Furthermore, the latter, as one of the means of achieving public interest, do not exist autonomously and separately from other factors that unite society and form the focus of public relations in general. Therefore, specific persons, on whom the main tax liability is imposed, depend on many aspects, in particular: the specifics of the legal system of the state, in which a specific tax or fee is established, the characteristics of economic, political, social, ideological, and other types of social relations, nature of dominant public interest, etc.

To be sure, the compulsory tax payment itself, the main general goal of its establishment, accentuation on the fiscal or on regulatory functions of the tax determine the composition and features of the obligated persons (subjects of tax legal relations). For example, for the successful implementation of the fiscal function of a compulsory tax payment, the payer of such a tax should be as universal as possible, involving the absolute majority of both individuals and legal entities, regardless of their citizenship, place of registration and other characteristics. The rules of formal logic prove it, according to the law of the inverse relationship of the scope and content of the concept, the more an additional number of attributes assigned to the prospective taxpayer, the less number of persons taxed. Therefore, the introduction of the regulatory function of the tax would often be impossible without the differentiation of taxpayers according to certain criteria important for the state to redistribute optimally tax pressure in the state, regulate such basic economic indicators as production, consumption, exports, imports of goods and services, braking negative trends emerging in various spheres of social relations, and promote desired social processes.

I. I. Kucherov emphasizes (Kucherov, 2009) that the direct definition of potential taxable persons is a matter of special importance since it is equated with the definition of objects of taxes and fees forming actually the basis of taxation. At the same time, the obliged subjects of tax legal relations differ from state to state, including different categories, vary by many features, in particular, social, economic, and others.

One of the most important criteria for differentiating persons subject to taxation in case of legal imposition of a compulsory tax payment is their personification by types, such as individuals or legal entities. Contrasting the above generic definition of taxpayers and tax collections enabling to understand a general nature of the person with the status of an obligated subject of tax legal relations, this distribution of taxpayers is most convenient for the legislator when establishing a direct legal regime for charging a specific tax or levy.

Under the direct establishment of tax obligations of legal entities and individuals, in fact, two types of taxpayers are consolidated legislatively. According to M. P. Kucheriavenko, exactly on the basis of the concept of a legal entity and an individual, the tax status of all types and their manifestations is formed (Kucheriavenko, 2005). For example, in the regime of tax duties and rights of legal entities, the specificities of involving branches, representative offices, and separate subdivisions of these persons into tax legal relations are determined, and their own legal status of obligated participants in tax legal relations is created. It is also possible to consider separately tax and legal statuses of various categories of individuals-taxpayers, in particular, on the basis of their tax residency or engagement in business activities.

Therefore, due to the differentiation of specific tax and legal statuses of taxpayers, the state receives sufficiently flexible and acceptable means for the society to regulate tax relations. Furthermore, a number of fundamental principles of tax and legal regulation are being implemented. For example, the principles that are provided for in domestic tax legislation by Article 4 of 
the Tax Code of Ukraine (Podatkovyi kodeks Ukrainy, p. 4.1 Art. 4). First, this is the principle of equality of all payers before the law, preventing any tax discrimination, that is, to ensure the same approach to all taxpayers, regardless of social, racial, national, religious affiliation, legal entity's form of ownership, citizenship of the individual, place of origin of capital. Second, this is the principle of social justice, according to which the establishment of taxes and fees should consider the solvency of taxpayers. Third, this is the principle of neutrality of taxation, that is, the establishment of taxes and fees in a way that will not affect the increase or decrease in the competitiveness of taxpayers.

The typology of taxpayers is embodied in the legal regulation of taxation relations while fixing the list of compulsory tax payments that make up the tax system of the state. Therefore, the whole set of established taxes and tax collections, according to the taxpayer criteria, can be divided into: a) collected only from individuals; b) collected exclusively from legal entities; c) collected both from physical individuals and legal entities.

A canonical example of tax with an individual as its only payer is the personal income tax (Podatkovyi kodeks Ukrainy, p. IV). In contrast, the corporate income tax is only for legal entities as taxpayers (Podatkovyi kodeks Ukrainy, p. III). Accordingly, such a differentiation of the taxpayer enables to establish an exclusive tax and legal regime for each of these taxes. In each case, the regime should facilitate the implementation of the basic functions of the mandatory tax payment, that is, fiscal and regulatory. Specificity of the legal regimes of these taxes is manifested at many levels, such as at fixing a special list of tax benefits, aimed at the maximum adaptation to the specificities of individuals and legal entities, stimulation of their socially useful activities considering their available opportunities. Furthermore, on the basis of such opportunities, as a rule, individuals are limited in performed tax obligations shifting part of them to other obligated participants in tax legal relations such as tax agents.

It should be noted that the current tax legislation of Ukraine (Podatkovyi kodeks Ukrainy, Art. 18) defines tax agents as persons on whom the Tax Code of Ukraine imposes an obligation to calculate, withhold from the income accrued (paid) to the payer, and transfer taxes in the appropriate budget on behalf of and at the expense of the taxpayer's funds. Moreover, it is indicated that tax agents are equal to taxpayers, have the rights and fulfil the duties established by the Tax Code of Ukraine for taxpayers. Indeed, tax agents are to fulfil a part of the duties of taxpayers, for which, by law, such a shift is provided. Meanwhile, it is necessary to clarify the issue of their "equalization with taxpayers." The point is that the unconditional feature, the fundamental principle of the legal status of tax agents is the derivativeness of their duties and rights from the basic legal status of taxpayers with assigned tax agents. This basic legal status of taxpayers is established primarily on the constitutional provision on the generally binding character of the obligation to pay taxes and fees (Konstytutsiia Ukrainy, Art. 67). Then this legal status of the taxpayer is detailed by general tax and legal regulations on the duties and rights of taxpayers (Podatkovyi kodeks Ukrainy, Art. 16, 17, 36). Accordingly, the legal status of taxpayers is initial in comparison with the legal status of their tax agents. Moreover, according to M. P. Kucheriavenko (Podatkovyi kodeks Ukrainy: postateinyi komentar, p. 263), it is important to consider that the duties of the tax agent arise upon availability to withhold and transfer the tax of the taxpayer, that is, upon availability of a corresponding source in the form of money of the taxpayer at his/her disposal. The situation when the tax agent transfers the tax of the taxpayer at own expense is excluded. Therefore, it should be emphasized that tax duties and the rights of tax agents are always derived from tax obligations and the rights of taxpayers.

Furthermore, tax agents together with taxpayers can coalesce into categories of taxable persons, subjects of tax legal relations, in a broad sense. This is due to assigning tax duties and tax rights to tax agents by tax legal regulations. I. Kucherov argues that taxable persons in taxation are physical individuals and legal entities, charged with calculating and paying or withholding and transferring taxes and fees to the budgets, in accordance with tax legislation. Moreover, the scientist observes that the direct content of these duties determines these individuals' legal status of taxpayers, payers of fees, or tax agents (Kucherov, 2009). Moreover, two interrelated remarks must be made to this thesis.

\section{Conclusion}

Such remarks rely on the fact that in some cases taxpayers' representatives can also enter tax relations as obliged persons. In accordance with the provisions of Article 19 of the Tax Code of Ukraine, the taxpayer manages the affairs related to the payment of taxes personally or through his/her representative (Podatkovyi kodeks Ukrainy, Art. 19). Personal participation of the taxpayer in tax relations does not deprive him of the right to have his/her representative, as well as the participation of the tax representative does not deprive the taxpayer of the right to personal participation in such relations. Representatives of a taxpayer are persons who can represent legitimate interests and manage the affairs related to the payment of taxes on grounds of law or a power of attorney. The power of attorney issued by a taxpayer (an individual) to represent his/her interests and manage the affairs related to the payment of taxes, must be certified in accordance with applicable law. Thus, a representative of a taxpayer exercises the rights provided for by this Code for taxpayers. Therefore, while considering taxable persons, payers of taxes and levies, their tax agents, and representatives of payers of taxes and levies should be specified. 


\section{References:}

Pryshva, N. Yu. (2004). Pravovi problemy reguliuvannia obovviazkovykh platezhív [Legal problems of regulation of obligatory payments] (Dissertation of Doctor of Law in specialty 12.00.07). K. (in Ukrainian)

Ilovaiskii, S. I. (1904). Uchebnik finansovogo prava [The textbook of financial law]. Odessa. (in Russian)

Rau, K. D.-G. (1867). Osnovnye nachala finansovoi nauki [The main principles of financial science] (Trans. from 5th German ed.). (Vols. 1-2). A. Korsak, V. Lebedev (Eds.). SPb.: Typography Maikov. (in Russian)

Tarasov, I. T. (2004). Finansy i nalogi: ocherki teorii i politiki [Finance and taxes: Essays on theory and politics]. In series Zolotye stranitsy finansovogo prava Rossii [Golden pages of the financial law of Russia]. M.: Statut, 618 p.

Kucherov, I. I. (2009). Teoriia nalogov i sborov [Theory of taxes and fees] (Monography). M.: ZAO YurInfoR, 473 p. (in Russian)

Ozerov, I. Kh. (1908). Osnovy finansovoi nauki [Fundamentals of financial science]. M.: Typ. assos. I. D. Sytina, 530 p. (in Ukrainian)

Isaev, A. A. (1887). Vremennik Demidovskogo yuridicheskogo litseia [Chronicale of the Demidov legal lyceum]. (Vol. 40). Yaroslavl. (in Russian)

Tsvik, M. V., Petryshyn, O. V., Avramenko, L. V. et al. (2011). Zahalna teoriia derzhavy i prava [General theory of state and law]. M. V. Tsvik, O. V. Petryshyn (Eds.). Kh.: Pravo. (in Ukrainian)

Kucheriavenko, N. P. (2005). Uchenie o naloge [The doctrine of the tax]. In 6 Vols. Kurs nalohovogo prava [Course of tax law]. (Vol. 3). Kh.: Legas; Pravo, 600 p. (in Russian)

Podatkovyi kodeks Ukrainy [The Tax Code of Ukraine] (2010). No. 2755-VI of December 2, 2010. Holos Ukrainy, 229-230. (in Ukrainian)

Konstytutsiia Ukrainy [The Constitution of Ukraine]. (1996). No. 254k / 96-VR of 28 June 1996. Vidomosti Verkhovnoi Rady Ukrainy [Bulletin of the Verkhovna Rada of Ukraine]. 30 p. (in Ukrainian)

Podatkovyi kodeks Ukrainy: postateinyi komentar [The Tax Code of Ukraine: itemized comment]. (2011). In 2 parts. M. P. Kucheriavenka (Ed.), 1. Kh.: Pravo, 704 p. (in Ukrainian) 